\title{
Investimento Direto Estrangeiro e Implicações Macroeconômicas no Brasil ${ }^{1}$
}

Antônio J osé Lima J r*

Frederico J ayme J $r^{* *}$

Resumo: Ao longo da década de 1990, uma das transformações mais visíveis ocorridas na economia brasileira foram os influxos de investimento direto estrangeiro (IDE) que apresentaram um crescimento sem precedentes, ao menos em valores absolutos. Nesse sentido, o propósito central deste estudo é analisar o desempenho do IDE, retratando o montante e o perfil desse tipo de investimento na economia brasileira e sua contribuição ao balanço de pagamentos e ao crescimento da economia. Os resultados obtidos apontam que a concentração dos investimentos externos no país foi através de fusões e aquisições, seja por meio da privatização dos serviços públicos ou através da venda de empresas privadas locais. Além disso, também se observou, ao longo do período, uma crescente participação do setor de serviços como principal setor de atração ao capital estrangeiro.

Palavras-Chave: Investimento Direto Estrangeiro, Brasil

A bstract: During the 1990s, there was a considerable growth in Foreign Direct Investment (FDI) to Brazil. The Central purpose of this paper is to study the FDI in Brazil, taking into consideration the volume, as well as the pattern of the FDI in the Brazilian Economy. Moreover, we intend to analyze its contribution to the balance of payments and economic growth in Brazil. The results suggest that merger, acquisitions and privatization have been the most important channel to attract FDI. Besides, the services sector increased their share in FDI n the last two decades.

Keywords: Foreign Direct Investment, Brazil

J EL Classsification: F10, F21, C23

1 Os autores gostariam de agradecer os comentários de dois pareceristas anônimos.

* Banco Central do Brasil. E-mail: antonio.medina@bcb.gov.br.

** Professor do Departamento de Economia e do Cedeplar, UFMG e pesquisador do CNPq. E-mail: gonzaga@cedeplar.ufmg.br.

Recebido em 21 de junho de 2007. Aceito em 09 de janeiro de 2008.

J únior, A .J .L.; únior, F.J . Investimento Direto Estrangeiro e imp licações M acroeconômicas... 


\section{Introdução}

A década de 1990 foi caracterizada por importantes transformações na economia brasileira. No plano internacional, a globalização financeira ampliou a integração dos sistemas financeiros mundiais, com uma conseqüente expansão no movimento de capitais internacionais. No início da década de 1990, a condução da política macroeconômica pelas economias desenvolvidas é marcada por um afrouxamento da política monetária, culminando numa significativa redução das taxas de juros internacionais. Essa redução dos juros, associada à elevada liquidez internacional e a recessão enfrentada por alguns países desenvolvidos, proporcionou aos mercados emergentes uma alternativa para os capitais internacionais. $\mathrm{Na}$ América Latina e África, a média do fluxo anual de entrada de investimentos diretos foi de US\$ 63 bilhões, entre 1990 e 1994, ao passo que no período 1995/98 este fluxo elevou-se para US\$ 145 bilhões.

No Brasil, a última década foi marcada pela consolidação do cenário de estabilidade econômica e por reformas de inspiração liberal, tais como a abertura comercial e financeira, a desregulamentação, a internacionalização da estrutura produtiva, a disciplina fiscal e o processo de privatizações. Nesse contexto, a economia brasileira aparece como um dos principais países receptores do fluxo de capitais internacionais, sobretudo após a implementação do Plano Real. Dentre esses recursos externos, destaca-se o papel do investimento direto estrangeiro (IDE), cujo volume, a partir da segunda metade da década, supera o volume de entrada de capitais de curto prazo, constituindo uma alteração significativa na estrutura de propriedade de capital no Brasil.

0 volume de IDE bruto aumentou consideravelmente, passando de uma média de US\$2,4 bilhões entre 1991 e 1995 para US\$ 22,3 bilhões entre 1996 e 1999. A participação do Brasil nos fluxos mundiais esteve em ascensão por quase toda a década de 1990, desde 1990 até 1998, onde os investimentos no país representaram 4,2\% do total mundial. A partir de 1999 a participação brasileira inicia uma trajetória de queda, culminando em 2006 com uma participação de apenas $1,4 \%$ dos fluxos mundiais de investimentos.

Os crescentes ingressos de IDEs na economia brasileira tiveram um papel primordial ao longo da década de 1990, uma vez que sustentavam os volumosos déficits na balança de transações correntes e viabilizavam a valorização cambial ocorrida após o Plano Real. A maior parcela desses investimentos foi direcionada para o setor de serviços, resultado, sobretudo, do processo de privatizações 
e de desregulamentação realizado pelo governo brasileiro. Neste processo de expansão dos investimentos diretos estrangeiros para 0 país é importante destacar que a principal forma de realização dos mesmos foram as fusões e aquisições transfronteiras. Configurouse, assim, um novo perfil para os fluxos de IDE, caracterizado pela compra de ativos já existentes, e, sem uma contribuição significativa do ponto de vista do aprofundamento da estrutura industrial. ${ }^{2}$

Diferentemente dos investimentos em portfólio, o IDE, em tese, deveria apresentar uma contrapartida de longo prazo, aumentando os níveis de poupança e de investimento de um país. No entanto, crescentes ingressos de IDE podem elevar a vulnerabilidade externa de uma economia, especialmente se este processo não for acompanhado de um aumento na receita das exportações.

Atualmente, os movimentos nos fluxos de IDEs são bastante complexos e estão ligados não apenas a uma série de fatores que rodeiam o ambiente competitivo em que as firmas atuam, mas também às características econômicas dos países hospedeiros e remetentes. Por essa razão, compreender o desempenho do IDE no Brasil é de fundamental importância para entender o desempenho recente da economia brasileira.

Nesse sentido, o propósito central deste trabalho é analisar 0 desempenho do IDE, retratando o montante e o perfil desse tipo de investimento na economia brasileira e sua contribuição ao balanço de pagamentos e ao crescimento da economia.

0 trabalho está estruturado em cinco itens, incluindo essa introdução. Na segunda seção, procurar-se-á investigar o montante de investimento direto estrangeiro distribuído na economia mundial, retratando os fluxos de entrada para os países desenvolvidos e para as economias em desenvolvimento nas duas últimas décadas. $\mathrm{Na}$ terceira seção, buscar-se-á mostrar o desempenho do investimento direto estrangeiro no Brasil, procurando identificar o montante e o perfil desse tipo de investimento a partir da década de noventa. Posteriormente, são apresentados os impactos que as empresas multinacionais exerceram sobre o crescimento e o balanço de pagamentos do país. Por fim, apresentam-se as conclusões finais provenientes da análise e suas implicações de política econômica.

${ }^{2}$ Esse novo perfil do IDE contrasta com aquele observado na década de 1970 , onde os investimentos concentravam-se na indústria, além de serem investimentos novos (greenfield). $\mathrm{Na}$ década de 1970, os investimentos realizados pelas EMN s representaram importante contribuição para o processo de substituição de importações, sobretudo nos setores de bens de capital e bens de consumo durável. (NONNENBERG; MENDONÇA, 2003). Sobre este ponto ver também Lacerda (2004) e Gonçalves (2005) 


\section{Recente Comportamento do IDE na Economia M undial}

Ao longo das duas últimas décadas, o sistema capitalista mundial foi marcado por um conjunto de transformações nas esferas comercial, produtiva, tecnológica, financeira etc., que configuraram um processo conhecido como globalização. No campo produtivo e financeiro, a globalização provocou expansão da internacionalização da produção, elevação da concorrência nos mercados produtivos, maior desregulamentação financeira, aumento do movimento internacional de capitais e maior integração dos sistemas financeiros mundiais. J untamente com essas transformações verificou-se uma expansão espetacular do fluxo mundial de IDE, sobretudo a partir da década de 1980.

$\mathrm{Na}$ tabela 1, encontra-se a evolução de alguns indicadores relacionados ao IDE desde a década de 1980. Observa-se que de um total mundial de entrada de IDE de aproximadamente US\$ 59 biIhões em 1982, este montante passa para US\$ 1,3 trilhão em 2006, após atingir o ápice de mais de quase US\$1,4 trilhão no ano 2000. Não apenas os fluxos de entrada de investimento estrangeiro, mas também os fluxos de saída assim como os estoques apresentaram significativo crescimento ao longo dos últimos 25 anos. ${ }^{3} \mathrm{Na}$ última metade da década de 1990, por exemplo, enquanto a entrada anual de IDE apresentou um crescimento médio de quase $40 \%$, os fluxos de saída apresentaram um aumento de cerca de 35\%.

Tabela 1. Indicadores selecionados de IDE na economia mundial, 1982-2006 (em bilhõese \%)

Fonte: UN CTAD, FDI/TNC database. Elaboração própria

Entretanto apesar da elevação significativa dos fluxos de IDE, no início dos anos 2000, houve um considerável declínio da entrada global de investimento externo. Entre 2000 e 2001, por exemplo,

${ }^{3}$ De acordo com a metodologia utilizada pela UNCTAD, a entrada de IDE é definida como o fluxo líquido, ou seja, são as transações de capital creditadas menos as debitadas entre os investidores diretos e suas filiais externas, englobando os empréstimos intercompanhias, os reinvestimentos e as participações no capital. 
a taxa de crescimento do fluxo de entrada de IDE foi negativa em cerca de $41 \%$. 0 principal fator responsável por esse declínio seria o baixo crescimento econômico da maior parte das economias do mundo. Além disso, quedas de valorização do mercado acionário mundial, baixas lucratividades das grandes corporações e uma diminuição das privatizações realizadas em alguns países em desenvolvimento também contribuíram para essa redução (UNCTAD, 2003). A partir de 2004, o ritmo de expansão dos fluxos de IDE volta a ganhar força devido sobretudo ao forte crescimento econômico mundial.

Quanto à distribuição dos ingressos de investimentos diretos externos entre as regiões, mais de dois terços do total mundial dos fluxos de entrada de IDE ao longo do período analisado sempre se dirigiram para as economias desenvolvidas, à exceção do período entre 1991-95 e do ano de 2005. Observa-se, através da tabela 2, que os países em desenvolvimento sempre mantiveram cerca de $25 \%$ do total mundial de ingresso de investimento estrangeiro, o que demonstra que a globalização não promoveu um incremento relativo de IDE para essas economias. ${ }^{4} \mathrm{No}$ ano 2000, por exemplo, apenas 0 montante de IDE recebido pelos Estados Unidos - US\$ 314 bilhões - foi superior aos investimentos realizados pelas transnacionais em todos os países em desenvolvimento - US\$ 252 bilhões - e na Europa Central e Oriental - US\$28 bilhões - somados.

Tabela 2. Média anual de entrada de IDE por região, 1970-2006 (em milhõese em \%)

Fonte: UNCTAD, FDI/TNC database. Elaboração própria

A participação do Brasil nos fluxos mundiais esteve em ascensão por quase toda a década de 1990, desde 1990 até 1998, período em que as concessões dos serviços públicos e as privatizações das empresas estatais, sobretudo do setor de serviços, atraíram grande

\footnotetext{
4 A principal alteração de percentual relativo de entrada de IDE é uma crescente participação da Europa Central e Oriental como um importante destino para os investimentos a partir da década de 1990. A pesar da participação desses países ser ainda pequena, a taxa de crescimento de investimento dirigido para essas nações foi muito elevada até a queda em 2003.
} 
parcela de investimentos diretos externos. A partir de 1999 a participação brasileira inicia uma trajetória de queda, culminando em 2003 com uma participação de apenas $1,8 \%$ dos fluxos mundiais de investimentos (Gráfico 1). Em 1998, o Brasil ocupava o 50 lugar na lista dos principais países receptores de IDE, caindo, em 2002 e 2003, para, respectivamente, $11^{\underline{a}}$ e a $16^{\underline{a}}$.

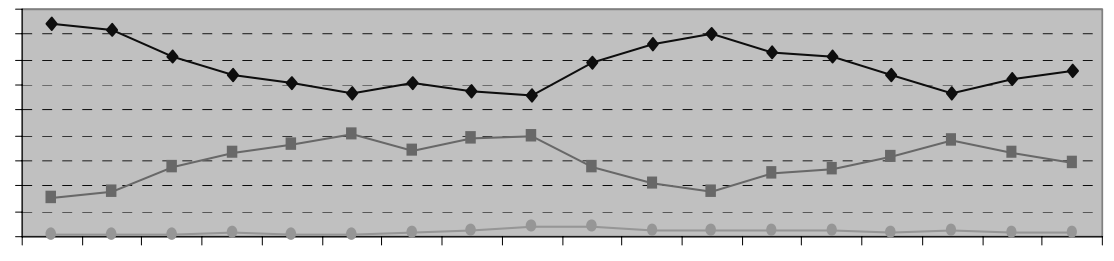

$\rightarrow-$

Gráfico 1. Participação por região no total dos fluxos mundiais de IDE, 19892006 (em \%)

Fonte: UNCTAD, FDI/TNC database. Elaboração própria

No que tange especificamente à distribuição dos fluxos líquidos absorvidos entre os países em desenvolvimento, verifica-se uma mudança de comportamento ao longo do período analisado. Durante a década de 1970, observa-se um grande influxo de IDE para os países da América Latina e Caribe, sendo o Brasil o principal receptor entre as economias em desenvolvimento. Neste período, cerca de $55 \%$ de IDE destinado aos países em desenvolvimento se dirigiam para as Américas, enquanto que a Ásia era destino de apenas 25\% (Gráfico 2 e Tabela 3). Ao longo da década de 1980 essa posição relativa vai sendo alterada, e na primeira metade da década de 1990 a Ásia já recebia quase 60\% do IDE destinado às economias em desenvolvimento. Essa perda de competitividade por parte dos países da América Latina ocorreu, sobretudo, devido ao baixo crescimento econômico, à instabilidade macroeconômica e à crise da dívida que atingiram essas economias durante os anos 1980.

A partir de meados da década de 1990, a América Latina reduziu a diferença em relação às economias asiáticas, principalmente devido à atração dos investidores internacionais pelo processo de privatização nessas economias. Entre 1996 e 2000, em média 40\% do IDE para os países em desenvolvimento foi para essa região. Apesar dessa elevação, em termos percentuais os valores recebidos ainda foram menores aos recebidos durante vários anos da década 


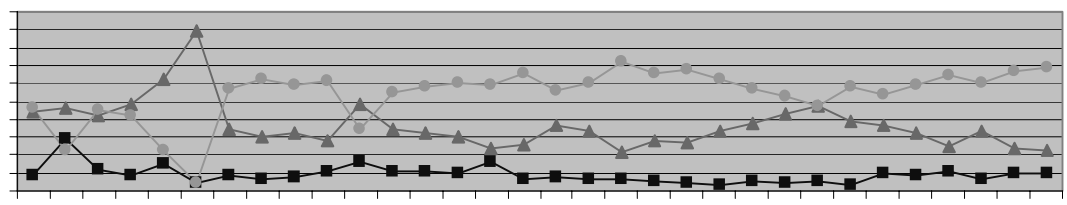

Gráfico 2. Participação por região no total dos fluxos mundiais de IDE, 19892006 (em \%)

Fonte: UNCTAD, FDI/TNC database. World Investment report 2004 para os anos de 2001 a 2003

de 1970. Entre 1970 e 1980, por exemplo, em média, a América Latina recebeu cerca de $58 \%$ do IDE destinado aos países em desenvolvimento (Tabela 3 ).

Nos últimos anos, entretanto, a América Latina voltou a apresentar sucessivas reduções no montante de IDE absorvido pelas economias em desenvolvimento. Entre 2004 e 2006, por exemplo, enquanto os investimentos que ingressaram na Ásia passaram de US\$ 171 para US\$ 260 bilhões, na América Latina ${ }^{5}$ esses recursos declinaram de US\$ 94 para US\$ 83 bilhões.

Ao longo de todo o período analisado observa-se um padrão de comportamento oposto na absorção de recursos externos entre a Ásia e a América Latina, enquanto que a região africana manteve uma certa estabilidade com uma participação muito baixa. Os períodos de crescimento no recebimento de investimentos externos por parte da Ásia coincidiram com períodos de decréscimo por parte da América Latina e Caribe, e vice-versa.

Com relação aos países em desenvolvimento, as alterações mais significantes em termos de influxos de IDE ocorreram no Brasil e na China. Enquanto o Brasil recebia cerca de $20 \%$ do investimento destinado às economias em desenvolvimento na década de 1970, esse percentual caiu pela metade nos anos 1990. A China, por outro lado, praticamente não recebia IDE nos anos 1970 e passou a ser o maior receptor entre as economias em desenvolvimento - responsável por mais de $27 \%$ do IDE absorvidos pelos países em desenvolvimento entre 2001 a 2003 - além de ter sido em 2002 o segundo maior país do mundo em recebimentos de investimentos externos (Tabela 3 ).

5 Em 2003, por exemplo, os ingressos de IDE na América Latina representaram apenas US\$ 44,7 bilhões. 
Tabela 3. Influxos de IDE para as economias em desenvolvimento, 1970-2006 (em \%)

Fonte: UNCTAD, FDI/TNC database. Elaboração própria

Neste processo de expansão dos investimentos externos, ocorrido principalmente ao longo da década de 1990, é importante destacar que a principal forma de realização dos mesmos foram as fusões e aquisições transfronteiras, configurando assim um novo perfil para os fluxos de IDE. Segundo a UNCTAD (1999), o volume de fusões e aquisições de empresas e o valor das operações cresceram significativamente nos anos 1990 em comparação à década de 1980. Uma vez que as empresas multinacionais estão cada vez mais buscando uma maior eficiência no novo ambiente competitivo exigido pela economia global, as fusões e aquisições tornaram-se fundamentais. Em vários períodos da década de 1990, a participação das fusões e aquisições representaram mais de $60 \%$ do fluxo mundial de investimento direto (Tabela 4). Nos últimos anos - 2005 e 2006 - verifica-se que o volume das fusões e aquisições continua muito forte devido sobretudo ao altos lucros corporativos e a intensa elevação dos preços das ações no mercado internacional.

Tabela 4. Relação entre investimentos em Fusão e Aquisição e IDE por região, 1992-2006 (em \%) 
Fonte: UNCTAD, FDI/TNC database. Elaboração própria

* média anual

Nota: Os dados referem-se a aquisições de mais de $10 \%$ dos ativos

Grande parte do total das F\&A transfronteiras - cerca de $80 \%$ foram realizadas nos países desenvolvidos ao longo das últimas décadas. Já a participação das economias em desenvolvimento, apesar de ter sido menor, não deixou de ser significativa. Em 2006, por exemplo, as operações de $F \& A$ nos países em desenvolvimento representaram cerca de $34 \%$ do total de IDE absorvido na região. Este desempenho só não foi maior devido à participação dos países do Sul e Sudeste Asiático, que foi baixa no período (27\%), ao contrário da América Latina e Caribe onde $81 \%$ do IDE foi na modalidade de $\mathrm{F} \& A$ (Tabela 4).

Laplane et al. (2001) mostra, comparativamente, que para os países do Sul e Sudeste Asiático a participação da modalidade de $F \& A$ nos fluxos de IDE nos anos 1990 foi menor e muitas vezes sem a perda do controle acionário, enquanto que na América Latina e sobretudo no Brasil essa participação foi elevada e em muitos casos envolvendo controle majoritário.

Com relação à distribuição dos influxos de IDE entre os setores da economia observa-se uma crescente participação do setor terciário (setor de serviços) como principal setor de atração ao capital estrangeiro. Através do gráfico 3 , verifica-se que enquanto o setor industrial foi responsável por cerca de $44 \%$ da entrada de IDE em 1988, em 2001 esse número caiu para aproximadamente $21 \%$, ao contrário do setor de serviços que passou de aproximadamente $39 \%$ em 1988 para cerca de 63\% em 2001. Este processo de crescimento significativo do setor terciário como receptor de IDE ocorreu inicialmente nas economias desenvolvidas e, posteriormente, nos países em desenvolvimento e foi resultado da abertura dos países à competição externa, dos programas de privatizações, da desregulamentação, dentre outros fatores. ${ }^{6}$
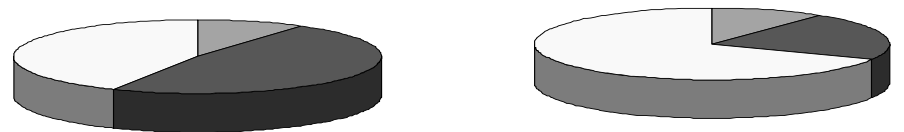

Gráfico 3. Fluxo de entrada de IDE por setor (em \%) Fonte: UNCTAD, WIR

6 Cabe destacar, segundo Laplane et al. (2001), que durante a década de noventa, embora o 


\section{IDE na ECONOMIA BRasileEIRA}

\subsection{A Evolução dos Investimentos}

A té o final dos anos 1970, o Brasil era o principal país hospedeiro de IDE entre os países em desenvolvimento. Entre 1970 e 1980, - país recebeu em média cerca de $21 \%$ dos investimentos externos destinados às economias emergentes (tabela 3). 0 regime de crescimento desenvolvimentista foi o principal determinante na atração dos investimentos externos naquele período. Segundo Nonnenberg e Mendonça (2003), a partir de 1969, com a estabilização da inflação, a retomada do crescimento econômico e a consolidação de um regime político francamente simpático ao capital estrangeiro, os investimentos externos começaram a se expandir no país. Além disso, a estratégia de substituição de importações adotada pelo governo Geisel também facilitava essa expansão. ${ }^{7}$

Entretanto, a década de 1980, caracterizada, de um lado, pela crise da dívida, baixo crescimento econômico e alta inflação, e, de outro lado, pela grande atratividade dos países asiáticos em desenvolvimento pelo investimento externo direto, reduziu consideravelmente o papel global do Brasil como receptor de IDE. Em 1979, por exemplo, cerca de 2,4 bilhões de dólares ingressaram no país sob a forma de IDE, enquanto que, em média, entre 1986 e 1989 ingressaram cerca de 1,3 bilhões. Até os três primeiros anos da década de 1990 os volumes absorvidos de IDE continuavam ainda baixos, sendo inclusive menores que os recebidos no final dos anos 1970.

A partir de meados da década de 1990, assistiu-se no Brasil novamente a uma entrada expressiva de investimento estrangeiro, transformando o país novamente em um dos principais pólos de atração para o IDE. Para Laplane et al. (2001) os principais fatores que contribuíram para o aumento desse fluxo foram, no âmbito interno, a desregulamentação, a abertura comercial e as privatizações, além do tamanho do mercado interno. Gonçalves (1999), por outro lado, enumera outros fatores internos, como o processo de reestruturação produtiva na indústria e nos serviços, as estratégias empresariais e o tamanho do mercado, aí compreendidos o nível de renda,

crescimento do setor de serviços tenha sido significativo no recebimento de recursos externos, a indústria continuou exercendo uma forte atração nas economias em desenvolvimento, principalmente no caso dos países do Sul e do Sudeste Asiático.

7 Aqui consideramos como IDE as operações em moeda nacional, mercadorias, conversões e reinvestimentos, ao contrário do item anterior onde também eram considerados os empréstimos intercompanhias. 
o histórico de crescimento, o potencial de crescimento e a criação do Mercosul. As razões externas dizem respeito ao fato que não apenas o Brasil foi contemplado com o aumento expressivo dos fluxos de IDE, mas também as economias desenvolvidas e os países em desenvolvimento de renda média, conforme foi verificado no subitem anterior.

O gráfico 4 apresenta a evolução dos ingressos brutos de IDE e o grau de internacionalização da economia brasileira ao longo da década de $1990 .^{8}$ Através do gráfico, constatam-se as elevações sucessivas dos fluxos de IDE para o Brasil, sobretudo entre 1996 e 2000. Em 2000, por exemplo, o país recebeu cerca de US\$32 bilhões em investimentos diretos externos, ou seja, trinta vezes mais do que recebia no início da década de 1990, sendo que esses fluxos corresponderam a quase $5,5 \%$ do PIB nacional.

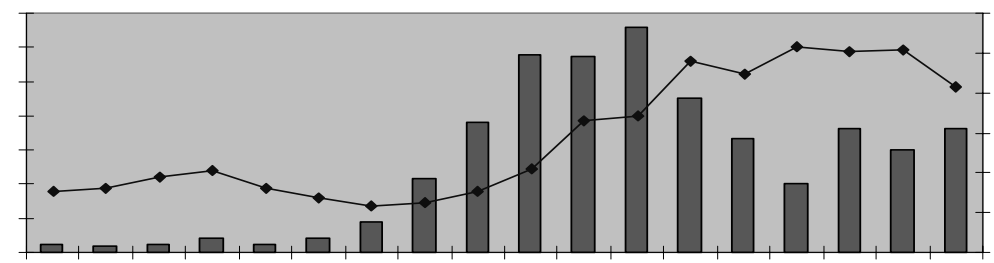

Gráfico 4. Ingressos brutos de IDE e grau de internacionalização, 1989-2006 (em US\$ milhões e em \%)

Fonte: UNCTAD, FDI/TNC database.

Nota: Inclui empréstimos intercompanhias.

Nesse período, a participação das empresas estrangeiras na economia brasileira aumentou consideravelmente. Medido pela relação entre o estoque de entrada de investimento externo e o PIB, - grau de internacionalização da atividade econômica que, entre 1990 e 1995, era de cerca de 8\%, alcança aproximadamente $17 \%$ em 2000 e cerca de $25 \%$ entre 2003 e 2005 . É importante considerar que parte desse aumento da internacionalização da atividade econômica deveu-se ao baixo dinamismo da economia brasileira.

A partir de 2001, iniciou-se um processo de desaceleração dos fluxos de IDE ao Brasil. Dentre os motivos desta expressiva redução

8 O grau de internacionalização medido pela UNCTAD representa a relação entre o estoque de entrada de IDE e o PIB. 
encontra-se no âmbito externo o baixo dinamismo das economias mundiais no perío do 2001-2003, fato que reduziu consideravelmente o número de fusões e aquisições transfronteiras. No caso brasileiro, de acordo com a UNCTAD (2004), esse forte declínio pode ser atribuído à normalização, ou seja, ao retorno das condições que precediam o programa de privatizações responsável pelo boom de IDE no final dos anos 1990. Além disso, o baixo dinamismo da economia brasileira e os baixos níveis de investimentos internos do governo, também foram fundamentais para essa retração dos investimentos externos. A partir de 2004, inicia-se um processo gradual de recuperação dos fluxos de IDE para o país, culminando em cerca de US\$ 18 bilhões no ano de 2006.

\subsection{A s Fusões e A quisições e as Privatizações}

Com relação às operações de fusão e aquisição no Brasil, ao longo da década de 1990, verificou-se que as mesmas ganharam impulso na segunda metade daquela década, com a privatização dos serviços públicos e com a venda de algumas empresas privadas locais, sobretudo instituições financeiras. Em 1997, por exemplo, $64 \%$ do IDE absorvido pelo país foi na modalidade de fusão e aquisição, ou seja, dos quase US\$19 bilhões que ingressaram no país na forma de IDE, cerca de US\$ 12 bilhões foram destinados à capacidade produtiva já existente na economia.

A tabela 5 demonstra que a diferença entre o total dos fluxos para o Brasil e as fusões e aquisições atribui-se às decisões de investir em novas plantas (greenfield) e/ou na ampliação de capacidade instalada. Assim, a concentração dos investimentos em $F \& A$, e não em novas plantas, não cria no curto prazo capacidade produtiva adicional nas economias. Enquanto um IDE novo adiciona capital imediatamente ao estoque de capital existente no país recipiente, uma $F \& A$ consiste na mudança de propriedade do ativo adquirido. A possibilidade de adição de capital ao estoque existente pelo adquirente pode ser imediata ou pode ser mais lenta.

Tabela 5. Fusão e Aquisição e IDE, 1993-2006 (em milhõese \%)

Fonte: UNCTAD, FDI/TNC database. Elaboração própria

Nota: Os dados referem-se a aquisições de mais de $10 \%$ dos ativos 
As $F \& A$ transfronteiras, como visto, foi uma das formas mais importantes de entrada de capital estrangeiro no país e que envolvia negociações, não apenas com empresas privadas de capital nacional, mas também com empresas públicas, por meio do programa de privatização brasileiro.

As privatizações realizadas pelo governo brasileiro foram decisivas para o forte ingresso de IDE ao país ao longo da segunda metade da década de 1990. De acordo com Laplane et al. (2001), no início do processo de privatização, em 1991, a participação estrangeira ainda era muito tímida, quando foram vendidas empresas industriais nos setores de siderurgia, mineração, petroquímica etc. 0 pagamento dessas empresas era realizado através de títulos e certificados públicos representando pouca entrada de recursos em moeda.

Tabela 6. Privatização e IDE*, 1995-2006 (em US\$ milhões e \%)

Fonte: Banco Central do Brasil

Nota: *Inclui operações em moeda nacional, mercadorias, conversões e reinvestimentos

Posteriormente, com a estabilidade econômica e com as operações envolvendo sobretudo os setores elétrico e de telecomunicações a participação estrangeira foi bastante significativa. ${ }^{9}$ Em 1999, por exemplo, alavancados pelos recursos destinados à privatização do setor de telecomunicações, os investimentos destinados à aquisição de empresas privatizadas atingiram um volume de quase US\$ 8,8 bilhões, representando quase $30 \%$ do IDE líquido que ingressou no país (Tabela 6).

A partir de 2001, o volume de investimentos externos em privatização no Brasil reduziu consideravelmente, juntamente com o início do processo de desaceleração dos fluxos de IDE destinados ao país, culminando, em 2003, com o fim das receitas com privatização. ${ }^{10}$ Esse forte declínio pode ser atribuído ao retorno do país às condições que precediam o programa de privatização.

9 Segundo Laplane et al. (2001) na privatização do setor de telecomunicações, por exemplo, o capital estrangeiro representou $60 \%$ do capital investido. Já na venda da empresa de energia Gerasul, a participação do capital estrangeiro foi total.

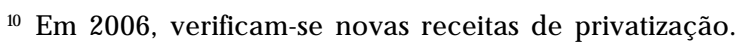




\subsection{Destino Setorial do IDE}

Quanto ao destino do IDE, uma característica importante observada ao longo da segunda metade da década de 1990 nos fluxos de IDE para o Brasil foi o incremento do setor de serviços frente ao setor industrial, seguindo a mesma tendência observada nos países desenvolvidos e alterando o perfil do capital estrangeiro investido no país. Através dos dados dos censos de capitais estrangeiros realizados pelo Banco Central, verifica-se a perda de atratividade do setor industrial ao longo da década de noventa. Em 1989, esse setor era responsável por $71 \%$ do estoque de capital estrangeiro absorvido pelo Brasil. Em 1995 essa participação cai para cerca de 66\% e no ano 2000 foi reduzida ainda mais, para quase 34\%.

A tabela 7 mostra a distribuição setorial em termos de estoque e do fluxo recente de IDE para a economia brasileira. Os estoques destinados ao setor primário sempre tiveram pouca representatividade, praticamente não significando mais que 2,5\% do total destinado ao Brasil ao longo dos anos 1990. Entretanto, a partir do ano 2000, a representatividade desse setor começa a ganhar destaque. Entre 2004 e 2005 o crescimento do fluxo de IDE para esse setor foi da ordem de $104 \%$. Ao que tudo indica com a redução o processo de privatizações no país, os investidores externos começam a direcionar suas atenções para segmentos exportadores como a agroindústria e a extração mineral. ${ }^{11}$

Tabela 7 Distribuição de IDE por Atividade Econômica (em US\$ milhões e \%)

Fonte: Banco Central do Brasil

Nota: *Dados de Censo de Capitais Estrangeiros (datas-base 1995 e 2000)

Conversões pela cotação do último dia útil do respectivo período

**Ingressos de investimentos e conversões de empréstimos financiamentos em IDE.

Conversões em dólares às paridades históricas

"1 Como esse fenômeno é bastante recente ainda necessita-se de estudos que comprovem essa alteração de perfil dos recursos externos destinados para o setor primário. Dentre os setores de destaque, entre 2001 e 2003, o setor de extração de petróleo foi responsável por cerca de $50,2 \%$ dos fluxos acumulados destinados ao setor primário, enquanto a extração de minerais e a agricultura/pecuária receberam 35,2\% e 9,7\%, respectivamente, dos recursos externos para esse setor. 
Com relação aos fluxos de IDE absorvidos pelo setor industrial, observa-se que após atingir $17 \%$ entre as atividades econômicas de aplicação de recursos no ano 2000, o setor industrial apresentou uma elevação na atratividade nos anos de 2001, 2002 e 2003, ao menos em termos percentuais, atingindo $36 \%$, uma vez que em termos de valor esses anos foram de sucessivas quedas.

Dentre os principais subsetores que mais absorveram recursos externos na indústria de transformação destacaram-se os setores automotivos, de produtos químicos, de alimentos e bebidas, de máquinas e equipamentos, de metalurgia básica, de material eletrônico e equipamento de comunicação e de artigos de borracha e plástico. J untos esses setores responderam por cerca de $77 \%$ do estoque destinado à indústria de transformação até o ano 2000 (Gráfico 5). Entre 2001-06, dentre os setores de destaque, apenas os setores de artigos de borracha e plástico, de máquinas e equipamentos e automotivo é que apresentaram uma queda expressiva de percentual - 3,1\%, 4,4\% e 14,1\% respectivamente - na participação dos fluxos acumulados para o setor secundário. Por outro lado, o setor de alimentos e bebidas aparece com percentual bastante significativo neste período de análise, elevando ainda mais sua participação.

Já o fluxo para o setor de serviços, após atingir 88\% em 1998 e $81 \%$ em 2000 na distribuição de recursos entre as atividades econômicas, apresentou uma queda de atratividade entre os anos de 2001 a 2006. Os fluxos acumulados nesse perío do representaram $54,5 \%$. Ao invés das aplicações em infra-estrutura que predominavam no final da década de 1990 - conseqüência das privatizações - os investidores internacionais estão direcionando seus recursos nos últimos anos, ainda que lentamente, em setores vinculados à exportação.
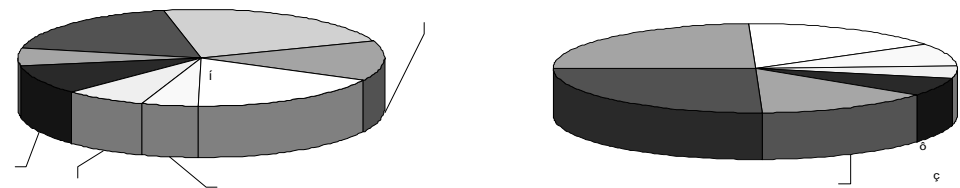

Gráfico 5. Setor industrial: investimentos por setor de destino (em \%) Fonte: Banco Central do Brasil

Dentre os principais subsetores que mereceram especial atenção por parte dos investidores estrangeiros destacaram-se os setores de telecomunicações, de intermediação financeira, de energia elétrica 
e saneamento básico e de serviços prestados a empresas, além do comércio varejista e atacadista. A penas os três primeiros setores responderam por cerca de $61 \%$ do estoque do setor terciário no ano 2000 (Gráfico 6). Setores como o de telecomunicações e o de eletricidade, gás e água que representavam muito pouco nos estoques de IDE em 1995 passaram a absorver parcela importante dos fluxos estrangeiros na segunda metade da década de 1990. ${ }^{12}$ Essa crescente participação desses dois subsetores foi resultado dos ingressos de recursos externos utilizados nos processos de privatização.

Entre 2001 e 2006, dentre os setores de destaque, o setor de energia elétrica e saneamento básico aumentou bastante sua participação, sendo responsável por cerca de $14 \%$ dos fluxos destinados ao setor de serviços, enquanto o setor de telecomunicações manteve sua fortíssima participação. Por outro lado, apenas o setor de serviços prestados a empresas é que teve uma queda expressiva de percentual - de $17 \%$ para $11 \%$ respectivamente - na participação dos fluxos acumulados para o setor terciário (Gráfico 6). Setores como de pesquisa e desenvolvimento, de educação, de saúde e serviços sociais em todo o período de análise apresentaram participação irrelevante - os fluxos acumulados, por exemplo, entre 2001-06 destes três setores somados foram de 0,37\%.
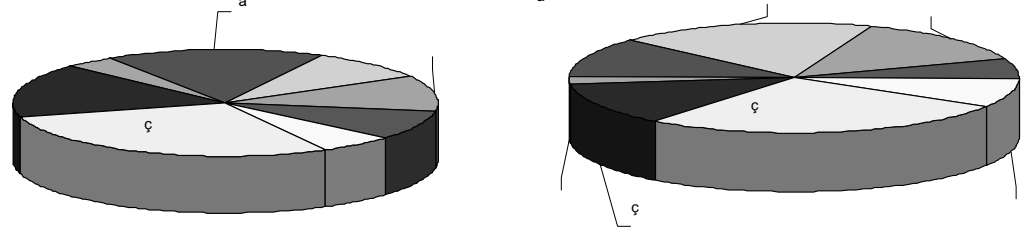

Gráfico 6. Setor de serviços: investimentos por subsetor de destino (em \%) Fonte: Banco Central do Brasil

De fato, o capital estrangeiro elevou bastante sua participação na economia brasileira ao longo da década de 1990, sobretudo em setores industriais já bastante internacionalizados e na área de serviços e infra-estrutura, onde a presença do capital estrangeiro era historicamente irrisória. Setores como o de telecomunicações, o elétrico, o de intermediação financeira, o petroquímico e o automobilístico

12 Esses dois setores somados representavam em estoques de 1995 cerca de 3,1\% das aplicações de recursos destinadas ao setor de serviços. 
foram alvo de profundas mudanças reguladoras com relação ao capital estrangeiro na atividade econômica do país (MATESCO et al., 2001).

A partir do início dos anos 1990, a regulação ao capital estrangeiro sofreu importantes mudanças que progressivamente foram sendo eliminadas com as restrições a atuação do capital externo no país. ${ }^{13}$ A flexibilização do monopólio do petróleo, a eliminação da distinção entre empresa brasileira de capital nacional e de capital estrangeiro, a autorização para as empresas estrangeiras atuarem na pesquisa e na exploração mineral e os estímulos do Governo Federal para a participação de sócios estrangeiros na privatização das telecomunicações e da energia foram algumas medidas que, junto com a abertura comercial, resultaram em um ambiente econômico mais atrativo para as atividades de internacionalização produtiva e financeira das empresas multinacionais no Brasil (LAPLANE et al., 2001).

Com relação ao setor de serviços, estas transformações se deram ao longo de um vetor de liberalização de mercado e, sobretudo, através do programa de privatizações do governo federal. A concentração desses investimentos em setores não comercializáveis pode vir a ocasionar no futuro uma maior remessa de lucros e dividendos sem equivalente geração de receita de exportação o que agravaria os problemas de balanço de pagamentos.

\section{0 s Impactos M acroeconômicos de A tuação das EM N s}

\subsection{Formação Bruta de Capital Fixo}

Os indicadores globais de fusões e aquisições, discutidos acima, refletem algumas tendências na estrutura produtiva do país. De acordo com estes indicadores, ao longo da década de 1990, grande parte do IDE destinou-se, no Brasil, na modalidade de operações em fusões e aquisições, muitas delas envolvendo controle majoritário e gerando concentração setorial do capital. Além disso, a baixa participação do IDE na modalidade de novas plantas (greenfield) reduziu a contribuição dos investimentos externos na formação bruta de capital fixo (FBCF). ${ }^{14}$

${ }^{13}$ As alterações produzidas na Lei de Informática em 1991, a Revisão Constitucional de 1993 e as emendas constitucionais a partir de 1995 são exemplos de mudanças na regulação do capital estrangeiro.

${ }^{14} \mathrm{O}$ período em que a modalidade de F\&A tornou-se predominante foi a partir de $1997 \mathrm{com}$ a privatização das empresas de serviços públicos. 
O gráfico 7 apresenta as relações IDE/PIB, IDE/FBCF e FBCF/PIB. De acordo com o gráfico, a relação IDE/FBCF apresentou um significativo aumento ao longo da década de 1990, atingindo em 1999 o valor máximo de cerca de $29 \%$. Entretanto, como a relação FBCF/ PIB - taxa de investimento global da economia - se manteve estável ao longo do período analisado, constata-se que a maior parte dos investimentos realizados foi destinado para a compra ou participação de investimentos já existentes e não para implantação e/ou ampliação de nova capacidade produtiva.

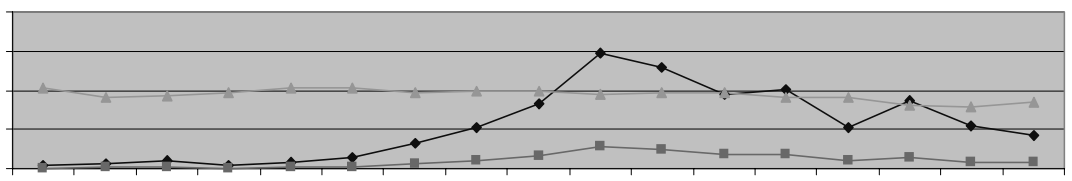

Gráfico 7. IDE, PIB e FBKF, 1990-2006 (em \%)

Fonte: Banco Central do Brasil; IBGE

Nota: * Fluxo líquido de IDE anual, incluindo operações em moeda nacional, mercadorias e reinvestimentos.

Segundo Laplane et al. (2001), dois fatores foram fundamentais para explicar essa estabilidade da taxa global de investimento na economia brasileira. 0 primeiro foi que o crescimento da demanda interna - sobretudo a partir do Plano Real - ocorreu principalmente através da capacidade produtiva ociosa, sem desencadear novos e volumosos investimentos. 0 outro fator foi que os encadeamentos produtivos resultantes dos novos investimentos, na maioria das vezes, foram transferidos para o exterior na forma de maiores importações de bens de capital. De Negri e Acioly (2004) também mostraram que as firmas estrangeiras têm maior propensão a importar, especialmente na indústria de bens de capital e de eletrônicos. ${ }^{15}$

Desta forma, a contribuição do capital estrangeiro para a formação bruta de capital fixo é menor do que a indicada pela relação IDE/FBCF, uma vez que uma relação direta entre a taxa de global de investimento e os fluxos de IDE deve ser analisada com cautela. Segundo Laplane et al.:

15 De acordo com os autores, uma firma importadora na indústria de bens de capital tem 20,5 vezes mais chance de ser estrangeira quando comparada com uma nacional. 
Contribuindo menos para a ampliação da capacidade produtiva e participando mais no estoque de capacidade produtiva já existente, a presença crescente do capital estrangeiro promove menores efeitos em termos de encadeamentos produtivose de geração adicional de renda e de emprego. (2001, p. 175).

Assim, verifica-se que o capital externo na modalidade de fusão e aquisição contribui menos para o crescimento econômico do país recipiente, o que contraria a idéia proposta por Hymer (1968) segundo o qual uma das vantagens da empresa multinacional seria a repartição de maneira eficaz dos produtos e fatores no mundo de forma a integrar a economia mundial.

\subsection{Impactos sobre o Balanço de Pagamentos}

\subsubsection{Balança Comercial}

0 grande fluxo de IDE destinado à economia brasileira ao longo da década de 1990 faz com que os fluxos comerciais brasileiros dependam cada vez mais da estratégia e da atuação das empresas transnacionais. Nesse sentido, alguns trabalhos buscaram captar o papel dessas empresas nos fluxos comerciais.

De Negri (2003) analisou a importância da origem do capital (estrangeira ou nacional) no período entre 1996 e 2000 sobre os fluxos comerciais das firmas individuais na indústria brasileira. Através da utilização de micro-dados, a autora estimou equações de importação e de exportação, controlados por outros fatores por meio de um painel para as empresas pertencentes à indústria de transformação. ${ }^{16}$

Os resultados encontrados pela autora demonstram que as empresas estrangeiras vis-à-vis as empresas nacionais apresentam um maior grau de abertura especialmente pelo lado das importações, ou seja, a diferença existente em favor das transnacionais é maior nas importações do que nas exportações. A autora constatou, através de seu modelo, "que a origem do capital das firmas tem impactos maiores sobre suas importações do que sobre suas exportações" (2003, p. 238).

Laplane e Sarti (2003) também constataram, através dos coeficientes de comércios das quinhentas maiores empresas brasileiras, diferenças importantes na inserção comercial das empresas estrangeiras e das nacionais (Tabela 8). Para os autores, apesar das filiais terem elevados coeficientes de exportação, sua maior a propensão

${ }^{16}$ Os fatores mais relevantes para explicar as diferenças nas exportações e importações das firmas estariam ligados a escala de produção, a produtividade, a tecnologia e a diferenciação de produto. 
a importar tornou a contribuição ao saldo comercial dessas empresas pouco significativa.

Tabela 8. Coeficiente de comércio das empresas estrangeiras e das nacionais nas 500 maiores empresas da economia brasileira (em \%)

Fonte: De Negri (2003)

As razões para a elevação das importações das firmas recémdesnacionalizadas seriam o aproveitamento por parte das novas filiais das redes de distribuição e fornecimento por parte das empresas multinacionais e a atuação dessas como uma base de comercialização de produtos fabricados em outros ramos da EMN. Além disso, as maiores importações podem estar relacionadas às compras de bem de capital, no caso de novos investimentos, e a modernização/reestruturação da firma no caso de fusão ou aquisição de uma dada empresa (DE NEGRI, 2003).

Hiratuka (2003), por outro lado, estudou o desempenho das filiais de empresas transnacionais (Ets) em termos de comércio exterior, nos anos de 1989, 1997 e 2000, no intuito de verificar como essas empresas se inserem no novo contexto de abertura comercial no Brasil nos anos 1990 e qual seria o impacto das mesmas sobre o saldo da balança comercial, bem como sobre a pauta dos fluxos comerciais.

Através de um painel com 96 empresas, onde estas foram escoIhidas de acordo com sua importância na estrutura econômica e obedecendo a um critério setorial de forma a ter uma razoável cobertura dos diversos setores, foram analisados dados sobre os valores, origem, destino e pauta de comércio tanto de exportações quanto de importações, além das propensões a exportar e a importar dessas empresas. Cada filial ainda foi classificada, de acordo com suas características comuns em uma tipologia que buscava caracterizar padrões típicos de integração comercial das filiais presentes no Brasil. ${ }^{17}$

${ }^{17}$ As filiais foram classificadas em não integradas, de integração global, de integração exportadora, de integração importadora, de integração regional e de integração exportadora moderada. As razões e um melhor detalhamento desta tipologia de classificação das filiais pode ser encontrada em Hiratuka (2003). 
Os resultados encontrados para as filiais não Integradas demonstraram que as mesmas têm uma orientação direcionada para o mercado interno, com reduzidos coeficientes, tanto de importação quanto de exportação. Como essas empresas, ${ }^{18}$ ao longo dos três anos de análise, representaram cerca de $20 \%$ de participação de vendas na amostra, Hiratuka (2003) concluiu que a orientação no atendimento ao mercado interno é uma característica que envolve grande parte das filiais brasileiras. Esse resultado encontrado pelo autor, confirma a idéia/hipótese de Dunning (1993) na qual uma das razões para as firmas produzirem no mercado internacional seria a busca de mercados, no intuito de ofertar bens e serviços para um determinado mercado interno. Mesmo no setor industrial, segundo o autor, "parcela importante das empresas estrangeiras continuam operando de maneira stand-alone, ao menos do ponto de vista comercial" (2003, p. 186).

As filiais com Integração Exportadora apresentaram saldos comerciais positivos, uma vez que resultaram de elevada propensão a exportar e de um coeficiente de importação reduzido. Essas filiais representaram apenas 4\% do faturamento da amostra no ano 2000. A maior parte das exportações desse grupo se concentrou em produtos primários e/ou intensivos em recursos naturais e com baixo grau de elaboração de produto. Neste grupo fizeram parte as filiais do setor de mineração, além uma siderurgia, duas empresas do setor de alimentos e um do setor de papel e celulose.

Por outro lado, as filiais com Integração Importadora tiveram como característica uma baixa propensão a exportar, juntamente com expressivo crescimento no volume e nos coeficientes de importação. Essas empresas, ao longo dos três anos de análise, representaram cerca de $22 \%$ de participação de vendas na amostra. Neste grupo, encontram-se filiais pertencentes aos setores de eletroeletrônica e informática, parte da química, farmacêutica e equipamentos de telecomunicações. São filiais bastante integradas com as matrizes sobretudo através da compra de insumos e componentes de conteúdo tecnológico, sem que isso refletisse em volumes de exportações significativos.

O grupo de filiais com Integração Regional são aquelas que implementaram uma estratégia de complementação produtiva e comercial dentro do Mercosul, embora a maior parte das vendas continue sendo o mercado interno. Essas empresas, ao longo dos

${ }^{18}$ Fizeram parte desse grupo 21 empresas de doze setores diferentes, havendo uma concentração de empresas do setor de minerais não-metálicos e higiene e limpeza. 
três anos de análise, representaram cerca de 38\% de participação de vendas na amostra. Para essas filiais verificou-se um aumento nos coeficientes de importação, sem modificações substantivas nos coeficientes de exportação. Destacaram-se neste grupo de empresas as filiais pertencentes à indústria automobilística. Diferentemente das filiais com Integração Importadora, esse grupo implementou uma forma de operação em que as filiais aumentaram o conteúdo exportado e importado dentro do bloco.

O grupo de filiais com Integração Exportadora Moderada caracterizou-se pela orientação exportadora acima da média da amostra e coeficientes de importação um pouco mais baixos próximos à média da amostra. Essas filiais representaram cerca de $13 \%$ do faturamento da amostra no ano 2000. Na pauta de comércio deste grupo é predominante os produtos primários e intensivos em recursos naturais e destacam-se as empresas siderúrgicas, alimentícias e do ramo de papel e celulose.

Por fim, as filiais de Integração Global obtiveram tanto crescimento importante nos coeficientes de importação quanto nos de exportação, apresentando um elevado grau de integração comercial. Entretanto, essas filiais representaram apenas 1,3\% do faturamento da amostra no ano 2000. Em termos de composição de pauta predominaram os produtos classificados como de fornecedores especializados tanto para as exportações quanto para as importações. 0 autor ressaltou ainda que essas empresas apresentaram um grau relativamente elevado de capacitação produtiva e tecnológica, sendo competitivas internacionalmente mesmo antes da abertura. ${ }^{19}$

Os resultados encontrados pelo autor demonstraram que apesar da abertura comercial ter elevado a integração comercial das filiais de ETs no Brasil, este resultado foi fortemente assimétrico, uma vez que essas empresas apresentaram maior propensão a importar do que a exportar. ${ }^{20}$ Assim, ao invés de reduzir a vulnerabilidade externa da economia brasileira, o desempenho dessas empresas, muitas vezes, foi no sentido contrário, agravando os desequilíbrios na balança comercial. ${ }^{21}$ Para Hiratuka (2003) a exploração do tamanho do mercado interno continua sendo prioridade para a maioria das filiais das empresas transnacionais no país. Dos seis padrões de integração

19 Foram quatro as empresas que compuseram esse grupo, sendo duas do setor de equipamentos de transporte, uma do setor de máquinas e equipamentos mecânicos e uma do setor de autopeças.

20 Este fato foi comprovado por Hiratuka (2003) através do crescimento dos fluxos de importação e exportação superiores ao conjunto da economia brasileira.

${ }^{21}$ A questão da vulnerabilidade externa da economia brasileira diz respeito ao fato de que os superávits em transações correntes não se sustentam por muito tempo em períodos de ... 
comercial, apenas as filiais com Integração Global apresentaram orientação de comércio voltado para o mercado externo.

Apesar da maior propensão a importar e da orientação para o mercado interno das filias das empresas transnacionais no Brasil, Arbix, De Negri e Salerno (2004) ressaltaram que as firmas industriais brasileiras internacionalizadas com foco na inovação tecnológica exportam mais do que as que não fazem este tipo de internacionalização. Mesmo estas firmas representando parcela pequena do faturamento do setor industrial brasileiro, existem benefícios, tais como maior qualificação e remuneração da mão-de-obra, dentre outros, que resultam da internacionalização da firma com foco da inovação tecnológica.

\subsubsection{Transações Correntes}

Os recursos externos que ingressaram no país sob a forma de IDE foram muito importantes para financiar os sucessivos déficits em transações correntes ao longo da década de 1990. A partir da fase de estabilidade econômica do Brasil até o período das sucessivas crises internacionais ${ }^{22}$ - época de câmbio sobrevalorizado - os déficits em transações correntes foram financiados não apenas pela crescente entrada de investimentos diretos, mas também pelos capitais de portfólio e pelos empréstimos e financiamentos externos. Em 1996 e em 1997, de acordo com a tabela 8, o IDE líquido financiou apenas $42 \%$ e $55 \%$ do déficit da balança de transações correntes (relação IDE/BTC).

A partir da crise asiática, houve não apenas uma forte saída de capital especulativo do país como também uma contração das linhas de empréstimos e financiamentos externos, fazendo com que o papel do investimento direto estrangeiro tenha se tornado mais importante. Em 1999 e em 2000, por exemplo, os cerca de US\$ 30 bilhões de IDE que ingressaram em cada ano foram mais do que suficientes para financiar os déficits de US\$25 bilhões e US\$24 bilhões na balança de transações correntes, respectivamente.

crescimento econômico, devido sobretudo à elevação das importações, que, têm uma elasticidade renda muito maior que as exportações (HOLLAND et alli, 1998; JAYME JR, 2003). Além disso, essa deterioração da conta corrente terá que ser compensada pela entrada de capitais. Como esses fluxos são afetados por choques externos, na ocorrência de qualquer choque que modifique a expectativa dos investidores/especuladores haverá uma fuga de capitais do país. 0 câmbio ficará pressionado e se desvalorizará com a saída de capitais. Essa desvalorização poderá contaminar vários preços da economia e a Autoridade Monetária elevará a taxa de juros da economia, podendo contrair a atividade econômica.

22 Este período vai de 1993 a 1997. 
Tabela 9. Saldo em Transações Correntes e Necessidade de Financiamento, 1994-2006 (em US\$ milhõese \%)

Fonte: Banco Central do Brasil

Nota: *Inclui operações em moeda nacional, conversões e reivestimentos

**Saldo em transações correntes mais investimentos direto estrangeiro

Nos anos de 2001 a 2006 mesmo com a queda nos fluxos de IDE para o Brasil, a relação IDE/BTC ainda continuou elevada, resultado da melhora da balança comercial brasileira que proporcionou a redução dos sucessivos déficits em transações correntes. A partir de 2003, o saldo em conta corrente tornou-se superavitário, resultado da combinação de elevação das exportações não acompanhado pelo aumento das importações. A demanda interna reprimida juntamente com o alto preço das commodities brasileiras no mercado internacional ajudaram a elevar ainda mais a relação IDE/BTC. A utilização do investimento direto estrangeiro como estímulo às forças produtivas e não para cobrir déficits em transações correntes é fundamental para a inserção externa da economia brasileira.

\subsubsection{Lucros e Dividendos}

Um outro tipo de impacto de atuação das empresas multinacionais sobre o balanço de pagamentos é através da conta de remessas de lucros e dividendos. J untamente com a balança comercial, o volume dessas reservas pode exercer uma pressão sobre 0 balanço de pagamentos. Ao longo da primeira metade da década de 1990 as remessas brutas de lucros e dividendos foram equivalentes aos montantes de IDE que ingressaram no país, chegando inclusive a superá-lo nos anos de 1993 e 1994. Em 1994, por exemplo, apenas as remessas brutas de lucros e dividendos resultante de rendas em investimento direto representaram cerca de $88 \%$ do influxo de IDE no período (Tabela 10).

Nos anos de 1996, 1997 e 1998 essas remessas aumentaram bastante atingindo mais de US\$ 7 bilhões em 1998. Esse crescimento, de acordo com Laplane et al. (2001), poderia estar associado à antecipação por parte das empresas devido à desvalorização cambial no ano seguinte, ao próprio crescimento dos fluxos de investimentos externos $^{23}$ às medidas de desregulamentação editadas pelo governo

${ }^{23}$ Enquanto as remessas cresceram cerca de 110\% entre 1995 e 1998, a elevação do ingresso ... 
federal ${ }^{24}$ e a própria realização de lucros por parte das empresas para cobrir posições deficitárias em outros mercados, dentre outros fatores. Apesar das remessas brutas terem se elevado na segunda metade da década, houve uma queda considerável no percentual dessas remessas em relação ao ingresso de IDE no período.

Tabela 10. Remessas Brutas de Lucrose Dividendos e IDE, 1990-2006 (em US\$ milhõese \%)

Fonte: Banco Central do Brasil

Nota: *a partir de 1979, o total de L\&D foi distribuído em rendas de investimento direto e em carteira

**Inclui operações em moeda nacional, mercadoria, conversões e reinvestimentos

Em 1999 e 2000, com a desvalorização cambial as remessas brutas reduziram consideravelmente para US\$ 5,5 e US\$ 4,2 bilhões, respectivamente. A partir de 2001, entretanto, elas tornam-se a elevar atingindo em 2006 o patamar de US\$ 17,3 bilhões. Mesmo com o aumento considerável das remessas brutas desde 0 início dos anos 1990, a participação das mesmas no ingresso de IDE, após declínio entre 1995 e 2000, aumentou consideravelmente sendo de 54,4\% em 2006. ${ }^{25}$

\section{Conclusão}

O objetivo deste trabalho foi o de analisar o desempenho do $I D E$, retratando o montante e o perfil desse tipo de investimento na economia brasileira e sua contribuição ao balanço de pagamentos e ao crescimento da economia.

Ao longo dos últimos vinte anos, o incremento de investimento direto estrangeiro na economia mundial foi extremamente significativo, sendo que os países em desenvolvimento sempre receberam em

de IDE no período foi de mais de $400 \%$.

24 Lei $n$ ㅇ.9. 249/95 e MP nำ1.602.

${ }^{25}$ Segundo Laplane et al. (2001) as comparações entre as evoluções dos ingressos de IDE e das remessas de lucros e dividendos sofre de duas ressalvas. A primeira que as remessas brutas não estão associadas apenas ao investimento direto, mas também aos investimentos em carteira. O segundo aspecto é que as remessas atuais de lucros e dividendos são conseqüências de decisões de investimento posteriores, havendo uma defasagem entre os dois fluxos. 
torno de $25 \%$ a $30 \%$ dos fluxos de IDE ao longo desse período. Neste processo de expansão dos investimentos externos, ocorrido sobretudo ao longo da década de 1990, é importante destacar que a principal forma de realização dos mesmos foram as fusões e aquisições transfronteiras, configurando assim um novo perfil para os fluxos de IDE. Além disso, também se observou, ao longo do período, uma crescente participação do setor de serviços como principal setor de atração ao capital estrangeiro.

Com relação à participação brasileira nos fluxos de IDE, depois de ser durante a década de 1970 o principal país em desenvolvimento na absorção de IDE, o Brasil assistiu a queda de sua participação percentual ao longo da década de noventa, apesar da elevação em termos absolutos. Da mesma forma que a maior parte dos países, a concentração dos investimentos externos na economia brasileira foi através de fusões e aquisições, seja por meio da privatização dos serviços públicos ou através da venda de empresas privadas locais, o que reduziu a contribuição do IDE na formação bruta de capital fixo, uma vez que grande parte dos investimentos realizados não foram para implantação de nova capacidade produtiva. Além disso, também se observou, ao longo do período, uma crescente participação do setor de serviços como principal setor de atração ao capital estrangeiro, o que reforça a evidência de que o mercado interno constitui a força motivadora das estratégias das empresas multinacionais que migram para o Brasil.

No que tange aos impactos sobre o balanço de pagamentos brasileiro, observa-se qe as firmas estrangeiras apresentaram maior propensão a importar do que a exportar ao longo da segunda metade da década de noventa, o que faz com que a contribuição das mesmas para o saldo comercial tenha sido pouco significativa. Apesar dessa constatação, os recursos externos que ingressaram no país sob a forma de IDE foram muito importantes para financiar os sucessivos déficits em transações correntes, principalmente no período 1994-2002.

Importante ressaltar, no entanto, que a natureza dos IDE no Brasil nos anos 1990 e 2000 não garantiu uma maior inserção internacional da economia brasileira, uma vez que boa parte desses investimentos representou apenas transferência de propriedade, sem aumento na Formação Bruta de Capital Fixo. A diminuição da vulnerabilidade externa da economia brasileira a partir de 2003 encontrou no aumento dos fluxos comerciais do Brasil em um período de crescimento da economia mundial acima da média do Brasil, e parece pouco ter a ver com os efeitos do IDE nos anos 1990 e 2000. De fato, o desempenho da 
balança comercial nos últimos anos relaciona-se com o período de crescimento principalmente da China e países da Ásia, e cabe pesquisa adicional para avaliar o papel do recente movimento de capitais sobre a diminuição dos indicadores de vulnerabilidade externa nos últimos anos.

\section{Referências}

ARBIX, G.; SALERNO, M. S.; DE NEGRI, J . A. Inovação, via internacionalização, faz bem para as exportações brasileiras. Rio de J aneiro, 2004 (mimeo).

BANCO CENTRAL DO BRASIL. Censo do Capital Estrangeiro. www.bcb.gov.br (acesso em 01/12/2007)

DE NEGRI, F. Empresas estrangeiras na indústria brasileira: características e impactos sobre o comércio exterior. In: LAPLANE, M.; COUTINHO, L.; HIRATUKA, C. (Orgs.) Internacionalização e desenvolvimento da indústria no Brasil. Campinas: Unesp, 2003. p. 215-250.

DE NEGRI, J . A ., ACIOLY, L. Novas evidências sobre os determinantes do investimento externo na indústria de transformação brasileira. Brasília: IPEA, 2004. 41p. (Texto para discussão; 1019)

DUNNING, J. H. Multinational enterprises and the global economy. Reading, Mass.: Addison-Wesley, 1993. 687p.

GONÇALVES, R. A economia política do investimento externo direto no Brasil. In: MAGALHÃES, J. P. (Org.) Vinte anos de política econômica. Rio de J aneiro: Contraponto, 1999. p. 235-258.

GO NÇALVES, R. A economia política Internacional. Rio de J aneiro: Paz e Terra, 2005.

HIRATUKA, C. Padrões de integração comercial das filiais de empresas transnacionais. In: LAPLANE, M.; COUTINHO, L.; HIRATUKA, C. (O rgs.) Internacionalização e desenvolvimento da indústria no Brasil. Campinas: Unesp, 2003, p. 165-213.

HOLLAND, M.; CANUTO, O.; XAVIER, C. Taxa de câmbio, elasticidades-renda e saldo comercial na economia brasileira. Revista Brasileira de Economia, v. 52, n. 2, p. 323-334, 1998.

HYMER, S. The international operations of national firms: a study of direct foreign investment. 1976. 253p. (Ph.D. Dissertation).

J AYME J R., F. G. Balance of payments constrained economic growth in Brazil. Revista de Economia Política. v. 23, n. 1, p. 62-84, 2003.

LACERDA, A.C. Globalização e Investimento Estrangeiro no Brasil. São Paulo: Saraiva, 2004.

LA PLANE, M. et al. Internacionalização e vulnerabilidade externa. In: LACERDA, A.C. (Org.) Desnacionalização: mitos, riscos e desafios. São Paulo: Contexto, 2000. p. 67-89.

LAPLANE, M. et al. La inversión extranjera directa en el MERCOSUR: el caso brasileño. In: CHUDNOVSKY, D. (Org.) El boom de inversión extranjera directa em el Mercosur. Buenos Aires: Siglo Veintiuno de Argentina, 2001. p. 123-208. 
LAPLANE, M.; SARTI, F. O investimento direto estrangeiro e a internacionalização da economia brasileira nos anos 90. In: LAPLANE, M.; COUTINHO, L.; HIRATUKA, C. (Orgs.) Internacionaliza ção e desenvolvimento da indústria no Brasil. Campinas: Unesp, 2003. p. 11-57.

MATESCO, V. et al. Fluxos mundiais de investimentos: a internacionalização da economia brasileira. In: LACERDA, A.C. (org.) Desnacionalização: mitos, riscos e desafios. São Paulo: Contexto, 2000. p. 105-128

NON NENBERG, M. J . B., MEN DO NÇA, M. J . C. Determinantes dos investimentos externos e impactos das empresas multinacionais no Brasil: as décadas de 1970 e 1990. Rio de J aneiro: IPEA, 2003. 68p. (Texto para discussão, 969).

SOBEET. Carta da Sobeet (vários números). www.sobeet.com.br (acesso em 02/12/ 2007)

UNITED NATIONS CONFERENCE ON TRADE AND DEVELOPMENT. World Investment Report. New York: United Nations Centre on Transnational Corporations (várias edições). 